\title{
Preface
}

\section{Aim of the Book}

This book describes and comments on the results of research devoted to the studies of phase assemblages in the $\mathrm{CaO}-\mathrm{SiO}_{2}-\mathrm{Al}_{2} \mathrm{O}_{3}-\mathrm{Fe}$ oxides chemical system (mentioned 'the system' thereafter), their stability and their evolution in our environment (temperature, pressure). Its aim is to be a research support, not only for researchers and development engineers but also more generally for others interested in materials sciences. Indeed; it concerns oxygen, silicon, aluminium, calcium and iron that are by mass the most abundant elements in the earth crust and the most widely used by human beings. Thus, not only does this show the diversity of the properties of the combinations of these elements, but also reflects the abundance as a primary reason for the diversity of their uses.

Consequently, the book is divided into two parts; the first one is devoted to a description of 'the system' using phase diagrams and the second one presents the properties of some of the constituents that are in widespread industrial and commercial use.

Much of the work reported in this book is fully original, as it reports records of the research that Dr François Sorrentino undertook in the chemistry department of Aberdeen University in the early seventies and then the research he carried out as manager of Mineral Research Processing Company devoted to the synthesis of minerals. The laboratory synthesis of calcium silicates and calcium aluminates, and their industrial manufacture were the main interests of the development of this Company.

\section{Summary of Part I - Description of the $\mathrm{CaO}-\mathrm{SiO}_{2}-\mathrm{Al}_{2} \mathrm{O}_{3}-\mathrm{Fe}$ Oxides Chemical System}

The first part is an exhaustive literature survey of 'the system'. References are quoted using the first three letters of the name of the first author followed by the year of publication. For example, ARA 1959 corresponds to Aramaki S. and Roy R. 
(1959) Revised equilibrium diagram for the system $\mathrm{Al}_{2} \mathrm{O}_{3}-\mathrm{SiO}_{2}$, Nature 184, 631. The major data relevant to this system and their combinations, useful for their applications in the daily lives of human being have been collected. Entirely reconstructed, revisited and redrawn phase diagrams are then described from the collected data, and experimental data from personal experience added. When data overlap or interfere, the author takes the responsibility of the choices that were made.

In each chapter, the constituents are identified by their formula in the introduction. A list of the most probable existing constituents is given and written both as chemical formula (e.g. $\mathrm{Ca}_{3} \mathrm{SiO}_{5}$ ) and oxides-based formula (e.g. $3 \mathrm{CaO} \cdot \mathrm{SiO}_{2}$ ). Common/historical names are also given when known, for instance when named after a locality such as the mineral, Andalusite (named after Andalusia), or when named after a person, typically the discovering geologist or chemist, for instance Wollastonite, named after William Hyde Wollaston (1766-1828). Then, the sub-chapter, entitled mineralogy, gives the mineralogical composition, the location and the mechanism of its formation. The main crystallographic characteristics and the polymorphic forms are then described in the sub-chapter related to crystallography. Solid solutions are only treated in the context of 'the system' that is narrower than the global chemical system. The stability of the phase assemblages depending on temperature and pressure is then reported in the sub-chapter dealing with phase diagrams. The experimental phase diagrams are redrawn from sets of experimental data found in the literature. Moreover, thermodynamic models have been used to calculate the phase diagram and compare it to its experimental counterpart. Finally, the last sub-chapter provides methods to synthesize the constituents that have been described thanks to the knowledge of their conditions of formation gained from phase diagrams.

\section{Summary of Part II - Applications of the $\mathrm{CaO}-\mathrm{SiO}_{2}-\mathrm{Al}_{2} \mathrm{O}_{3}-\mathrm{Fe}$ Oxides Chemical System}

Part II describes the main applications of the oxides within 'the system' (except for the primary oxides where applications are reported in part I). It is hardly surprising to find that there is a large diversity of applications found with minerals and substances containing these elements. The most common combinations are oxides (silicon, aluminium, iron), or non-oxide minerals such as carbonates or sulphides. Other combinations between these elements allow us to extend the fields of applications of the phase relations known in the simpler system. The work presented in this part, is not only a bibliography synthesis, although the data come, in a large part from the literature, but they have been enriched by personal experience, in the field of hydraulic binders, refractory glass and ceramics that are part of Dr François Sorrentino's professional career.

The applications are divided into three levels of applications, the last one being the closest to the end-user or the customer (table P.1). The first level describes the application of the $\mathrm{CaO}-\mathrm{SiO}_{2}-\mathrm{Al}_{2} \mathrm{O}_{3}-\mathrm{Fe}$ oxides chemical system with a minimum of 
TAB. P.1 - Examples of the three levels of applications of the $\mathrm{CaO}-\mathrm{Al}_{2} \mathrm{O}_{3}-\mathrm{SiO}_{2}-\mathrm{Fe}$ oxides system.

\begin{tabular}{|c|c|c|c|}
\hline $\begin{array}{l}\text { Starting } \\
\text { material }\end{array}$ & First level & Second level & Third level (end use) \\
\hline $\mathrm{CaO}$ & Agriculture & Slag forming, cement & Civil engineering (buildings) \\
\hline $\mathrm{SiO}_{2}$ & Aggregates & Glass, cement & $\begin{array}{c}\text { Civil engineering (cladding material } \\
\text { for buildings), cooking ware, } \\
\text { container }\end{array}$ \\
\hline $\mathrm{Al}_{2} \mathrm{O}_{3}$ & Refractory & $\begin{array}{l}\text { Aluminium }(\mathrm{Al}), \text { gems, } \\
\text { glass (with } \mathrm{Ge}) \\
\text { abrasive }\end{array}$ & $\begin{array}{l}\text { Vessel, kiln lining, building, aircraft } \\
\text { devices, wave guide }\end{array}$ \\
\hline $\begin{array}{l}\mathrm{Fe} \\
\text { oxides }\end{array}$ & Pigments & Steel, slags & $\begin{array}{c}\text { Car industry, steel bar, military } \\
\text { devices }\end{array}$ \\
\hline
\end{tabular}

treatment such as crushing or grinding. For example, the use of $\mathrm{Fe}_{2} \mathrm{O}_{3}$ as a pigment, the use of $\mathrm{CaO}$ in agriculture or silica as quartz for aggregates. The second level concerns the use of 'the system' as a precursor for the synthesis of other materials such as the manufacture of steel by reduction of $\mathrm{Fe}_{2} \mathrm{O}_{3}$ or the combination of $\mathrm{CaO}$, silica, alumina and iron oxides to manufacture cement. The third level represents the end level for which the application is close to the end-user or to the customer.

The fields of applications in 'the system' reported in part II are construction, metallurgy, glass and ceramics but also specific uses such as refractory materials and fillers.

\section{Acknowledgement}

I would like to thank Prof. Denis Damidot and Dr Charles Fentiman for taking part in the process of writing and editing this book. I also would like to thank my wife Dr Danielle Sorrentino for her unconditional support.

Dr François Sorrentino 
